DOI: https://doi.org/10.15688/lp.jvolsu.2018.2.1

UDC 1(091)

LBC 87.3

\title{
THE ISSUE OF FREE WILL AND DIVINE PREDESTINATION IN THE WESTERN AND EASTERN PATRISTICS IN THE CONTEXT OF ORTHODOX (SOTERIOLOGICAL) AND PHILOSOPHICAL DIFFERENCES
}

\author{
Olga V. Chistyakova \\ Peoples' Friendship University of Russia, Moscow, Russian Federation
}

\begin{abstract}
The article is devoted to the consideration of the most important problem of the correlation of freedom, free will and Divine predestination having arisen in both Western and Eastern patristics since the birth of the Christian faith. These problems pervaded all the centuries of Christianity, starting with the period of apologetics and then in the era triadological theological and Christological disputes (IV-VII centuries.). The paper presents a comparative analysis of the patristic Graeco-Byzantine tradition and Western patrology (mainly of Augustine Aurelius). The reflexive analysis of patristics is presented in the context of consideration of the most important philosophical and religious doctrine of Christianity about soteriology, i.e. spiritual salvation of man. Soteriological ideas of Christianity were closely connected with Christian anthropology and outlined the path of self-knowledge, self-improvement and moral elevation of each person. This justified the prospect of restoring the individual's lost likeness to God, which in turn meant achieving a state of spiritual unity with the Creator. In this regard, a significant place in the article is given to the ideas of deification, spiritual ascent to the absolute in correlation with the reflection of the concepts of freedom and free will of an individual.

The theoretical discussion between the representatives of the Eastern and Western patristics of the problem of correlation of the gift (mercy) of God and the active efforts of a man to achieve salvation caused in the early Christian discourse centuries-old controversy about the predestination, foresight, the grace of God and human free will. The article presents the difference between the positions of the Eastern and Western fathers of the Church on this issue. From the point of view of Eastern Christian thinkers, predestination is both absolute meaning the supernatural destiny of all personal and social events, and relative recognizing the important role of man in achieving unity with God, and hence spiritual immortality. According to Augustine, on the contrary, a person can get true freedom only as a result of the perception of the gift of God, i.e. God's grace, which meant that salvation is possible only with the decisive participation of God, because human efforts without the help of the Creator are not enough to achieve this cherished goal.

Key words: Western Christianity, Eastern Christianity, Patristics, freedom and free will, Divine predestination, deification, soteriology.
\end{abstract}

УДК 1(091)

ББК 87.3

\section{СВОБОДА ВОЛИ И БОЖЕСТВЕННОЕ ПРЕДОПРЕДЕЛЕНИЕ В ВОСТОЧНОЙ И ЗАПАДНОЙ ПАТРИСТИКЕ В КОНТЕКСТЕ ОРТОДОКСАЛЬНЫХ (СОТЕРИОЛОГИЧЕСКИХ) И ФИЛОСОФСКИХ РАЗЛИЧИЙ}

Ольга Васильевна Чистякова

Российский университет дружбы народов, г. Москва, Российская Федерация 
Аннотация. Статья посвящена рассмотрению важнейшей проблемы соотношения свободы, свободы воли и Божественного предопределения, возникшей как в западной, так и в восточной патристике с момента зарождения христианского вероучения. Указанная проблематика пронизывала все века становления христианства, начиная с периода апологетики, а затем и в эпоху триадологических и христологических богословских споров западных и восточных отцов церкви (IV-VII вв.). В работе проводится компаративный анализ святоотеческой греко-византийской традициии западной патрологии (преимущественно Августина Аврелия), философско-антропологических вопросов соотношения свободы воли, Божественного предопределения и предвидения. Рефлексивный анализ патристики представлен в контексте рассмотрения важнейшего философскорелигиозного учения христианства о сотериологии, то есть духовном спасении человека. Значительное место в статье уделяется идеям обожения, нравственного совершенствования личности, духовного восхождения к Абсолюту. Показаны основные положения учений Максима Исповедника, Афанасия Великого, Григория Нисского и других византийских отцов церкви.

Ключевые слова: западное христианство, восточное христианство, патристика, свобода и свобода воли, Божественное предопределение, обожение, сотериология.

Непреходящая значимость философских идей греко-византийской патристики и роль святоотеческого наследия в истории культуры, на наш взгляд, в наибольшей степени выявляется в сравнительном анализе с соответствующими положениями западной патрологии в период перехода от античности к средневековью.

В эллинистический период (когда зарождающаяся христианская культура впитывала подходящие ей идеи античной Греции и Рима) наряду с интеллектуальным осмыслением роли государства, религии, науки возникает и актуальная потребность в рефлексии индивидуальной значимости человека в этом мире, возможностей личностного познания смыслов жизни, взаимосвязи человека и Бога/богов, гносеологических путей постижения Абсолюта.

Дать ответы на подобные вопросы пытались многообразные мистико-гностические течения и философские учения, возникавшие в раннесредневековый период. Однако в этом многообразии мистического, религиозного и философского гносиса наибольшую силу приобретало новое монотеистическое вероучение.

Христианское миросозерцание и оформляющаяся теология постепенно становились духовной основой крепнувшего средневекового общества. Однако, несмотря на единый идейный источник, христианство в Византийской империи и западноевропейском ареале формировалось своеобразными путями и обладало значительными различиями. Обсуждение любой философской проблемы в западноевропейской и византийской философии носило оригинальный характер и сущностно отличалось как по содержанию, так и по форме. Кро- ме того, вырабатываемая латинской и греческой патристикой религиозная догматика западного и восточного христианства имела свои специфические особенности и характерные черты. Собственно именно здесь начиналось будущее разделение западной и восточной церквей.

IV в. в истории патристики считается кульминационным, поскольку в этот период вырабатывается основная ортодоксальная догматика христианства и обозначается значительное расхождение западноевропейского и византийского средневековья, имманентно связанного с христианством. Различия западного и восточного (византийского) христианства особенно наглядно проявили себя в обосновании философско-антропологических идей, гносеологических категорий и нравственных ценностей.

В патристике, компаративному анализу которой в контексте рассмотрения свободы воли и предопределенности человека абсолютным волением Бога посвящена наша статья, особенно наглядно проявляются эти тонкие различия глубокого осмысления сути взаимоотношений человека и Бога в западной и восточной догматике. Отмечая великие заслуги патристики, Гегель писал: «Все вопросы о природе бога, о человеческой свободе, об отношении к богу, который есть объективное, о происхождении зла и т. д. были рассмотрены отцами церкви, и то, к чему мысль приходит относительно этих вопросов, они внесли и восприняли в христианскую систему догматов. Природу духа, порядок спасения, то есть ступени одухотворения субъекта, его воспитание, поступательное шествие духа... эти его 
обращения они также познали согласно его моментам, рассмотрели дух в его свободе и в его глубине» [7, с. 87].

Уже с IV в. западная церковь начала латинизироваться на основе своей богослужебной литературы и специфической литургии. Необходимо отметить, что связанное с римской традицией западное христианство, отличавшееся рационализмом и культовым практицизмом, менее тяготело к богословскому теоретизированию, чем его восточное направление. Вопрос о соотношении дарованной Богом свободы и практической ее реализации индивидом в тонкостях и хитросплетениях личностного пути к Богу был одним из основных в работах отцов западной и восточной церквей, но он также остается актуальным и для современных теологов и философов.

\section{Концепция свободы воли и предопределения \\ в восточной патристике:}

\section{сотериологическая определенность}

В греко-византийской патристике при доминировании теоцентрического мышления такие существенные философские вопросы, как свобода человека и предначертанность его судьбы, взаимоотношения индивида с Богом, возможности Богопостижения, во многом обусловливались сотериологическим учением христианства. Сотериология обосновывала возможности спасения каждого индивида и раскрывала «тайны» вечной духовной жизни после смерти. Потому категория спасения в христианстве стала основополагающей и имела двоякий смысл. Во-первых, спасение трактовалось как самая значимая цель моральных и религиозных устремлений человека и, вовторых, как высший дар Творца. Обоснование идеи спасения шло вразрез с грехопадением, поскольку идеалы спасения намечали праведный путь совершенствования и нравственного возвышения человека. Тем самым открывалась перспектива восстановления утерянного человеком богоподобия и обретения им духовного бессмертия. Основную роль здесь выполнял догмат о Богочеловеке, поскольку Воплощение Христа объяснялось целью искупления греховного состояния всего человечества, что давало возможность все- общего и индивидуального спасения. Таким образом, сотериологическая проблематика в христианском вероучении была тесно связана с философским и теологическим обоснованием феномена Богочеловека или Боговоплощения.

Спецификой обоснования идей спасения и искупления в восточной патристике было объяснение первоначального Божественного замысла, который состоял в обожении всего человечества и тварного мира и осуществлении свободного единения каждой личности с Творцом. Чтобы показать пути достижения заветного спасения и духовного единства человека с Богом, вводился догмат о Богочеловеке, согласно которому воплощенный Сын Божий помогает субъекту вернуть утерянное богоподобие в ходе индивидуального нравственного пути к Абсолюту. Святой Афанасий Великий в своей работе писал: «Мы стали побуждением к Его воплощению; для нашего спасения Он показал столько человеколюбия, что принял на Себя человеческое тело и явился в нем» [5, с. 196].

В христианском мировоззрении спасение есть слияние человеческого и божественного в вечности, восстановление утраченных человеком первозданных образа и подобия Богу. Святоотеческая традиция намечала путь спасения как особое единство, некий внутренний синтез всего человечества и индивидуальной природы каждой личности. Академик С.С. Аверинцев отмечал глубокое понимание спасения в христианстве, которое рассматривалось как «...предельно желательное состояние человека, характеризующееся избавлением от зла - как морального (“порабощенности греху”), так и физического (смерти и страдания), полным преодолением отчуждения и несвободы» [3, с. 107]. Нам представляется, что понятие спасения в трудах отцов церкви носит апофатичный смысл: ведь идеалы спасения отрицают смерть, тленную природу человека, саму возможность греха, несовершенство и неправедность, которые существуют в бренном мире.

Следуя идеям восточных отцов, сверхсущий Бог целенаправленно принимает ответственность за греховность природы человека, чтобы устранить разрыв между Божественным и человеческим мирами. Тем са- 
мым феномену Богочеловечества придавался характер противоречивости, хотя изначально в Богочеловеке как личности исключена любая антиномичность или конфликт. Григорий Богослов, подчеркивая этот тонкий момент, отмечал, что здесь разрешается и вопрос о человеческой свободе и свободе воли. Согласно святому Григорию, своим Боговоплощением Иисус восстанавливает естество человека в его целостности и всеобщей сущности, куда включены свобода и свобода воли каждого индивида. Григорий Богослов писал: «Христос, когда увидел, что душепагубный грех истребил в человеческом теле все, что было вложено небеснаго... тогда, для возвращения Себе Своего достояния, не других помощников послал против болезни, а... Безсмертный, став смертным, пришел чрез Матерь-Деву, чтобы целиком спасти целаго человека» (курсив наш. - О. Ч.) [8, с. 36].

Необходимость пришествия Богочеловека и его крестная смерть отцами церкви обосновывались и онтологически, и антропологически. Люди, потерявшие величие «венца Божественного творения», сами по себе уже не обладают возможностью обожения и достижения единства с Творцом. Для этого им необходима помощь и духовная мощь Иисуса Христа. Кроме того, феномен Богочеловечества нес и сильную психологическую нагрузку. По мысли С.С. Аверинцева, смерть и воскресение Христа следует характеризовать как «событие, апеллирующее к самым пронзительным чувствам человека и предъявляющее к этому человеку самые неимоверные требования, коль скоро он “куплен дорогой ценою”» [2, с. 184], поскольку греховность человечества искуплена самим Господом.

Уже на заре христианства один из первых отцов церкви святой Иустин намечал сотериологическую традицию: «Когда исполнилась мера нашей неправды ...Бог по безпредельному человеколюбию... принял на Себя грехи наши. Он предал Сына Своего в искупление за нас, Святаго за беззаконных, Невиннаго за виновных, Праведного за неправедных, Нетленнаго за тленных, Безсмертнаго за смертных» [11, с. 381]. Однако идеи искупления и спасения восточной патристики не устраняли антиномизма христианской антропологии. Потеряв свое априорное онтологическое равенство с Творцом, человек уже не может вернуть его как сущностное естество человечества, но только как акт благости Бога, как величайший дар Господа (в творениях отцов церкви это вылилось в учение о сущности и благодати Божией). По сути в работах восточных отцов вырабатывались идеи, объясняющие соотношение Божественного и человеческого миров. Праведная жизнь в земном мире приводила к реализации главной цели христианина - спасению в мире Божественном. По сути идеалы спасения способствовали формированию в лоне христианского монотеизма нового образа личности, так называемой «новой твари». Ведь спасение априори предполагало самосовершенствование и самопознание человека в возвышающем его процессе постижения Бога. Это и должен быть путь обожения, то есть восприятия личностью лучших Божественных качеств. При этом крестная смерть Богочеловека в работах восточных отцов показана прежде всего в качестве средства, без которого было бы невозможно достижение человеком целей обожения.

Обоснование патристикой учений об искуплении и спасении представляет ту часть христианской сотериологии, которая показывает ее реализацию со стороны Бога. Однако на этом этапе цели обожения еще не выполняются полностью. Поэтому восточные отцы разрабатывают пути и средства спасения, которые должен предпринимать сам человек для достижения вхождения в духовное единство с Творцом.

Обратившись к знаменитому творению Григория Нисского «Об устроении человека», обнаруживаем глубокую философскую идею о том, что спастись должны не индивидуумы каждый сам по себе, а общзая цельная природа человеческой личности. Святой Григорий, объясняя противоречивое отношение Божественного и земного миров, прежде всего пытался теоретически обосновать взаимосвязь между духовным и телесным, вечным и бренным, природой греховной и абсолютно лишенной зла. «Ибо далеко отстоит известное о первообразе от происшедшего по образу» [9, с. 51]. Рассуждения Григория здесь носят философско-антропологический характер. Он использует категории всеобщего и единичного. Творение Богом человека изна- 
чально носило характер всеобщности, всеединства, которое заложено в каждом индивиде, и именно эта всеобщая природа человечества может быть восстановлена в соответствии с Божественным Первообразом. Более того, всеединство человеческого естества определяет личностные качества человека и сущностно отличает индивида от личности. Отсюда сообразность человека Творцу заключается не в каком-то индивидуальном физическом элементе, а в общей духовной природе, объединяющей человеческий и Божественный миры.

Лишь в результате первородного греха непротиворечивость всеобщей природы личности приобретает внутреннюю дихотомичность: к всеобщности присоединяется $и н д и$ видуальность. В качестве индивидуального естества она выступает частью целого, одним из компонентов Универсума. К различимым свойствам индивидуальности человека относятся многообразие проявлений чувственности, влечения и страстные устремления, греховные помыслы и тяготение ко злу. Однако благодаря изначально заложенной Богом совершенной природе личности сохраняется и ее всеобщая основа, раскрывающаяся в абсолютных проявлениях добра, красоты, ума, мудрости, добродетели, любви к людям и Богу и т. д. Сущность человека, согласно Григорию Нисскому, заключается именно в этой противоречивости природы человека: «Человеческая природа есть середина между двумя крайностями, отстоящими друг от друга, - природой божественной и бесплотной и жизнью бессловесной и скотской» $[9$, c. 52]. Для спасения необходимо осознанно и свободно восстановить всеобщую природу человека, ту, что от Бога. Поскольку человек не пассивное существо, он должен самостоятельно прокладывать путь к своему бессмертию, а значит, к Богу.

Отметим, что в этом философско-антропологическом объяснении взаимоотношений человека и Бога заключалось, в частности, основополагающее различие между двумя направлениями патристики. Представители восточной традиции - Афанасий Великий, Григорий Нисский, Василий Кесарийский, Григорий Богослов, Иоанн Златоуст и др. - исходили из идеи вселенского, соборного человека, предполагая духовное единение людей, принадлежащих к церкви Христа. Для западной патристики (особенно для Августина) было характерно рассматривать индивидуальную природу человека, в своем становлении раскрывающуюся Абсолюту.

Обсуждение восточными и западными святыми отцами проблемы соотношения дара (милости) Бога и активных усилий человека для достижения спасения вызвало в раннехристианском дискурсе многовековые споры о предопределении, благодати и свободе воли. В восточном христианстве категории «свобода воли» и «свобода» имеют различную смысловую значимость. Восточные отцы церкви под свободой воли понимали свободное определение человека в выборе своего жизненного пути: праведного, ведущего к Богу или отвергающего абсолютную нравственность от Бога и тяготеющего к греху и злу. Понятие свобода означало наивысшее проявление духовного совершенствования в религиозной сфере. Таким образом, теоретизирование о свободе воли выступает в патристике значимым аспектом рассмотрения свобо$\partial b l$ как таковой. Обоснование идеи свободы содержалось в объяснении антиномичной взаимосвязи между абсолютной свободой Творца, обусловливаемой Его божественной сущностью, и относительной свободой воли индивида, зависимой от его изначальной греховной природы. Божественная предопределенность здесь тонко и достаточно диалектично сочеталась с наличием свободы воли и свободы выбора каждого субъекта. В возвышающем человека процессе обожения, ведущего к спасению, главенствующее место занимает благодать Бога, помощь Всевышнего, а затем собственные нравственные и духовные усилия, сила его воли и сознательной праведной жизни. Русский религиозный философ Сергий Булгаков, осмысливая идеи греческих отцов церкви, спасение считал «личным подвигом» человека. Он утверждал, что спасение является всеобщим обожением человеческого естества (вспомним здесь Григория Нисского) и осуществляется оно не над человеком, не извне его, оно есть «...внутреннее благодатное действие в человеке, которое совершается при участии человеческой свободы, не помимо самого человека» [6, с. 236]. 
Однако как ни пытались греко-византийские мыслители решить проблему взаимодействия Божественного и человеческого, все же не устранялся внутренний антиномизм христианского учения, совмещающий противоположные положения: благодатное всемогущество Бога и индивидуальную ответственность субъекта за принимаемые решения и совершаемые поступки. Посредством действия благодати реализуется Божественное предопределение судьбы человека - достижение им спасения и эсхатологического бессмертия. Предопределенность носит как абсолютный характер и означает сверхъестественное предначертание всех личностных и общественных событий, так и относительный, признающий за человеком важную роль в достижении единства с Богом, а значит, и духовного бессмертия.

Яркое воплощение эти идеи нашли в сочинениях святого Иоанна Дамаскина, который утверждал, что человеческая судьба и поступки зависят не от провидения, а от свободной воли и свободы личностного выбора. В обсуждение проблемы он вводит категорию «предвидение» и отмечает, что Господь все предвидит, но далеко не все предопределяет. Обладая всемогуществом, Бог предвидит человеческие дела, но, предоставляя человеку свободу, не предопределяет их. Следует отметить, что в рамках западной патристики оказалось возможным существование различных точек зрения по этому вопросу. В Византии же тезис Иоанна Дамаскина был основополагающим для всех представителей патристики на протяжении многовековой истории этой цивилизации.

Несмотря на рефрен в пользу человека, внесенный святым Иоанном, все же и в западной, и в восточной патристике в рассмотрении дихотомии «Бог - человек» предельно абсолютизировалась сторона Абсолюта, а другая - личностная - принижалась. Представитель греческой святоотеческой традиции Ириней Лионский объяснял это тем, что только Бог является Творцом человека и всего живого, а человек, даже будучи «венцом» Божественного творения, не может обладать такими функциями. Поэтому, чтобы достичь спасения и бессмертия, «...человек призывается усмотреть в самом себе ничто и в акте сми- рения раскрыть это ничто богу» [4, с. 449]. В своем стремлении к Богу человек должен полагаться на праведность своего пути и на высшую благодать как акт свободной воли Творца. Это двуединство действий человека и Бога приближает индивида к достижению целей обожения. Идея необходимости синергийного единства Божественной благодати и активной деятельности человека является характерной для восточной патристики и наличествует в работах почти всех греческих отцов.

Подобные мысли были свойственны уже ранним отцам. Ориген в сочинении «О началах» отмечал, что ни личностная свобода без познания Божия мира, насколько оно может быть дано человеку, ни знание Божественного само по себе, без личностного стремления к чему-то абсолютному, не побуждают индивида к совершенствованию. Позднее Григорий Нисский утверждал, что даже потеряв свободу, человек обладает волей, которая в гармоничном взаимодействии с Божией благодатью дает ему возможность сознательно начать свой путь заново, отбросив ошибки и падения, искупая грехи новой нравственной жизнью. Таким образом, разумное сочетание свободы воли человека, благодати и Божественного предвидения должно способствовать восстановлению утраченного подобия на любом этапе жизни человека, но в зависимости от прилагаемой активности самого субъекта.

Однако, несмотря на то что путь к спасению обусловливается свободной волей и свободой выбора человека, эти свобода и воля всегда предваряются благодатью Бога. Человек всегда вправе выбирать между путем обожения и духовного единения с Богом или отрицания Бога, принятия тварности, зла. Достижение спасения невозможно без беспредельной искренней любви к Творцу и всему человечеству. Любовь к другому человеку рассматривалась как необходимый этап духовного восхождения и единения с Богом и как объективный критерий свободы выбора и принятия Бога.

Григорий Нисский учил, что свобода проявляется тогда, когда человеческая любовь превосходит свое собственное естество, забывает себя и всеобъемлюще распространяется на другое существо. Личность есть из- 
бавление от природной необходимости, возможность свободно себя определять, способность выйти за рамки своей обусловленности, чтобы произошло преобразование индивидуальных внутренних качеств во всеобщее абсолютное ощущение любви, что достижимо только в состоянии единства с Богом. Каждый человек должен осознанно встать на путь обретения свободы и выбора Бога. Обладающий разумом человек «сознательно ведет свою природу», а потому может подчинять свои чувства и страсти, уберечь самого себя от присутствия зла в своей жизни. В унисон идеям святого Григория размышлял Иоанн Дамаскин: «По необходимости свобода решения соединена с разумом, потому что или человек не будет разумным существом, или, будучи разумным, будет господином своих действий и независимым. Посему неразумныя существа и не суть свободны, ибо они более ведутся природою, нежели ведут» [10, с. 109].

Восточная патристика приближала Бога к человеку. Сотворив человека, обладающим свободой воли, Бог приобретал своего рода бессилие перед ней. Свобода человека имеет исток в милости и всемогуществе Творца, а потому Бог не может проявлять принуждение или силу по отношению к воле индивида. В этом также проявляется всеобъемлющая любовь Господа к сотворенному им человеку. «Божественная воля будет всегда покоряться блужданиям, уклонениям, даже бунтам воли человеческой, чтобы привести ее к свободному согласию» - отмечал по этому поводу В.Н. Лосский [12, с. 244].

Мы видим, что проблема соотношения Божественного предопределения, предвидения и свободы воли в своей основе так же антиномична, как и понимание самого человека с точки зрения христианского ортодоксального учения. Человек как объект Божественной благодати оказывался существом, пораженным грехом, но в то же время он наделялся совершенно осознанной свободой, рациональностью, способностью и возможностью осуществлять выбор в любой период своей жизни. По сути этот антиномизм устанавливает метафизическое отношение между абсолютным всемогуществом Творца и приниженностью личностной воли. Как некий синтез это противоречие снималось в категории «прови- дение», однако в полной мере эта проблема в патристических текстах не была решена.

\section{Свобода воли и предопределение с точки зрения западной патристики}

Августин Аврелий старался преодолеть крайности учения манихеев с их утверждением абсолютно греховной сущности человека и противоположной концепции Пелагия и его последователей, учивших, что первородный грех не нанес столь глубокий ущерб человеческой природе, чтобы индивид самостоятельно не мог бороться со злом, встав на путь добродетели и нравственности. Пелагиане не отвергали действия самой благодати Бога, но на фоне абсолютизации свободной воли субъекта она была почти незаметна, вторична, что шло вразрез с формирующейся христианской ортодоксией.

В противоположность манихеям Августин не отрицает частичного действия свободы воли человека. Однако, критикуя пелагиан, он в то же время отстаивает идею о том, что без значимой роли благодати и предопределения Господа человек самостоятельно не в состоянии достичь обожения и спасения. Настаивая на решающей роли предопределения, Августин Аврелий приуменьшал возможности воли индивида, поскольку это могло привести к абсолютизации человеческой свободы.

Согласно мыслителю западной церкви провидение Творца созидает «град земной», но управляет сотворенным миром только Бог своим волением и действием. Поэтому в своем главном труде «О граде Божием», а также в творении «Об исправлении и благодати» Августин предельно абсолютизирует роль благодати Божией, которая активизирует свободу воли человека в процессе движения к спасению.

Следуя Августину, сущность человека как нравственного существа состоит не только в его духовном бессмертии, но и обладании свободой и свободой воли, что позволяет каждой личности определить свой жизненный выбор как путь добра, возвышения к Богу или путь зла, ухода от Него. Свобода воли с необходимостью обусловливает существование противоположностей, которыми наполнен мир: праведность и греховность, добро и зло, на- 
града за нравственность и кара за совершенное зло. Свобода человека заключается в воле выбирать между этими противоположностями. Творец, обладая абсолютным предвидением, знал выбор первого человека и будущую утрату им богоподобия, но все же в свое высшее творение Бог заложил свободу и право индивидуального выбора между добром и злом. Августин писал: «Он и самого человека сотворил правым, с тем же самым свободным произволением, как существо хотя земное, но достойное неба, если он останется в единении с своим Творцом; если же от Него отступит, постигнет и его злополучие, свойственное этого рода природе. Предвидя, что и он также отступит от Бога, преступивши закон Божий, Бог не лишил его однако же способности свободнаго произволения» [1, с. 319].

В концепции Августина налицо антиномичное понимание воли и свободы. Человек, обладающий свободой воли, раскрывается им как существо противоречивое в своей сущности и эта противоречивость углубляется и нарастает по мере протекания жизни индивида. В философском плане воля вырисовывается как феномен, определяющий и направляющий человека в его стремлении к Богу. Однако сама воля приобретает некоторое иррациональное, негативноезначение, она может составлять и демоническое начало личности, что говорит о возможности преобразования воли в страстное и греховное своеволие.

В указанном выше контексте понимание Августином свободы воли нивелируется в связи с его осмыслением христианского учения о Божественной благодати и предопределении. В его интерпретации ортодоксального понимания этого вопроса поступки человека оказываются независимыми от его собственной воли. Истинную свободу человек может получить лишь в результате восприятия дара Бога, то есть Божьей благодати. В сотериологической перспективе спасение возможно лишь при значимом участии Бога, поскольку только индивидуальных усилий для достижения заветной цели обожения недостаточно. «И истребляется зло не чрез уничтожение какой-либо привходящей природы или известной ея части, а чрез оздоровление и исправление природы испорченной и извращенной. Итак, произвол воли тогда по истине свободен, ког- да не служит порокам и грехам. Таким он был дан от Бога, и потерянный... может быть возстановлен только Тем, Кем мог быть дан» [1, с. 30]. Таким образом воля человека становится своеобразным средством действия Божественного предопределения. Жизнь индивида не поддается рациональному объяснению и прогнозированию, поскольку в контексте августиновской концепции не зависит от поведения, поступков, волевого выбора, а полностью зависит от Божественного произволения.

Дихотомизм августиновского понимания свободы и воли реализуется здесь в наибольшей степени. Тезис о свободе воли преобразуется в антитезис о ее несвободе, а на этой основе образуется противоречие, которое частично находит разрешение в созданном теоретическом феномене «града Божиего». В трансцендентном духовном царстве благодать Бога в качестве высшего дара освободит индивида от желания грешить. Свобода человека представлена здесь как возможность к греху, которая может реализоваться в любой период жизни индивида. Однако полное отсутствие потребности грешить делает путь человека безгреховным и праведным, что приводит его в царство Божие. Святой Августин рассуждает в этом плане: «Люди будут тогда обладать и свободною волею потому, что грехи уже не будут в состоянии доставлять удовольствие. И свобода эта будет выше, потому что очищена будет от удовольствия грешить для непреложного удовольствия не грешить. Первая данная человеку... когда он был сотворен правым, свободная воля могла не грешить, но могла и грешить; эта же будущая свобода будет могущественнее той, потому что будет уже в состоянии невозможности грешить. И такою она будет по дару Божию, а не по возможности, заключающейся в самой природе ея... Так как природа наша согрешила, потому что могла и согрешить, то, очищаясь при посредстве обильнейшей благодати, она приводится в состояние той свободы, при которой не могла бы грешить» [1, c. 400-401].

Таким образом, свобода человека в граде Божием означает невозможность совершения греха, поскольку сохраняется воля и стремление человека к добру, совершенству, познанию, нравственности и т. д. Но все это 
даровано человеку Богом и зависит от благодати Всевышнего. Получалось, что, с одной стороны, провозглашалось присутствие Бога в жизни каждого индивида; при этом потенциальная возможность свободы человека обосновывалась как любовь и благодать Творца, проявленные к человеку. С другой стороны, утверждались врожденное бессилие и рабская участь человеческой души, непоправимо изменившейся в результате первородного греха. В дальнейшем подобный взгляд будет сущностно отличать западную традицию философии от восточной, византийской. Отметим, что в греческой патристике человек свободен не только потому, что рожден со свободой воли, но и потому, что изначально обладал подоби$e м$ с Богом. Здесь доминировал взгляд на человека как на активное и деятельное существо, способное очень многое менять в своей жизни и самостоятельно достигать высоких целей, в том числе спасения.

В западной патристике спасение неминуемо подготавливалось Божественным предопределением, поскольку человек был поставлен в зависимость от благодати Творца. В восточной патристике намечались пути и средства совершенствования и очищения субъекта в процессе обожения и достижения духовного бессмертия. Здесь нравственный катарсис личности мыслился как часть общечеловеческой природы, что не только идейно обосновывало феномен спасения, но и выносило вопросы христианского гносиса на первый план. Это означало выработку определенных путей и методов (иногда даже практик, например, в исихазме) познания БогаТворца, что одновременно означало самопознание человека на пути самосовершенствования и приближения его разумного естества к Абсолюту. По мере того как человек возвышался на пути обожения и обретения собственного совершенства и свободы, возрастало и личностное самосознание и постижение Божества. Преподобный Максим Исповедник утверждал: «Никто не может истинно благословлять Бога, если не освятил тело добродетелями, и душу не просветил истинными познаниями» [13, с. 293].

Следуя восточным отцам, Бог своей абсолютной свободой обусловливает свободу земного бренного мира. Однако эта предоп- ределенность не нарушает творческого саморазвития личности. Спасение в восточном богословии «заслуживается», «зарабатывается» в процессе моральной, нравственно-духовной, религиозной жизни. В западной патристике (например, у Августина) приближениек спасению даруется Богом в качестве благодати.

В восточной святоотеческой традиции не отрицается действие благодати Божией. Здесь она выделяется как вспомогательная сила в достижении бессмертия. Предопределенность выражает не только предвидение индивидуальной судьбы человека, но и признает за ним определенную роль в достижении свободы и восстановления принципа Богоподобия.

Все же, несмотря на нацеленность восточных отцов на обоснование гармонического действия Божией благодати и человеческих сил, в их учениях, как и в западной патристике, абсолютизируется Божественная сторона этой антиномии, а другая сторона - человек с его высокими духовными качествами - недооценивается. Тем не менее сотериологию и учение о свободе воле в западной и восточной патристике объединяет утверждение человека деятельным существом, способным на любом этапе жизненного пути выбрать добродетельную жизнь, тем самым приближая себя к Богу. В целом в византийской традиции это выражено в большей мере и более отчетливо, нежели в западной, где смещен рефрен в пользу обоснования большей силы Божественного предопределения.

\section{СПИСОК ЛИТЕРАТУРЫ}

1. Августин Блаженный. О граде Божием / Августин Блаженный // Августин Блаженный. Творения. В 4 т. Т. 3. - СПб. : Алетейя ; Киев : УЦИММПресс, 1998. -595 с.

2. Аверинцев, С. С. Западно-восточный генезис литературных канонов византийского средневековья / С. С. Аверинцев // Типология и взаимосвязь средневековых литератур Востока и Запада. М. : Наука, 1974. -575 c.

3. Аверинцев, С. С. Спасение / С. С. Аверинцев // Философская энциклопедия. В 5 т. Т. 4. - М. : Сов. энцикл., 1967. -592 c.

4. Аверинцев, С. С. Христианство / С. С. Аверинцев // Философская энциклопедия. В 5 т. Т. 4. М. : Сов. энцикл., 1967. -592 с. 
5. Афанасий Великий. Творения. В 4 т. Т. 1 / Афанасий Великий. - М. : Изд-во Свято-Преображенского Валаамского монастыря, 1994. - 471 с.

6. Булгаков, С. Православие / С. Булгаков. M. : Teppa, 1991. $-416 \mathrm{c}$.

7. Гегель, Г. Лекции по истории философии. Соч. Т. ХІ / Г. Гегель. - М. : Соцэкгиз, 1937. - 560 с.

8. Григорий Богослов. Творения. В 2 т. Т. 2 / Григорий Богослов. - М. : Свято-Троицкая Сергиева Лавра, 1994. - 554 с.

9. Григорий Нисский. Об устроении человека / Григорий Нисский. - СПб. : Аксиома, 1995. $-174 \mathrm{c}$.

10. Иоанн Дамаскин. Точное изложение православной веры / Иоанн Дамаскин. - Ростов н/Д : Братство Святого Алексия : Изд-во «Приазовский край», 1992. - 446 с.

11. Иустин Философ. Творения / Иустин Философ. - М. : Паломник : Благовест, 1995. - 484 с.

12. Лосский, В. Н. Очерк мистического богословия восточной церкви. Догматическое богословие / В. Н. Лосский. - М. : Центр «СЭИ», 1991. $-288 \mathrm{c}$.

13. Максим Исповедник. Умозрительные и деятельные главы / Максим Исповедник // Добротолюбие. В 12 т. Т. 6. - М. : Паломник. - 156 с.

\section{REFERENCES}

1. Augustine of Hippo. O grade Bozhiem [On the City of God]. Augustine of Hippo. Tvoreniya. $V 4 t$. T. 3 [Writings. In 4 vols. Vol. 3]. Saint Petersburg, Aleteya Publ.; Kiev, UCIMM-Press, 1998. 595 p.

2. Averintsev S.S. Zapadno-vostochnyy genezis literaturnykh kanonov vizantiyskogo srednevekovya [Western-Eastern Genesis of the Byzantine Medieval Literary Canon]. Tipologiya $i$ vzaimosvyaz srednevekovykh literatur Vostoka $i$ Zapada [Typology and Interrelation of the Western and Eastern Medieval Literature]. Moscow, Nauka Publ., 1974. 575 p.

3. Averintsev S.S. Spasenie [Salvation]. Filosofskaya entsiklopediya. V 5 t. T. 4 [Encyclopedia of Philosophy. In 5 vols. Vol. 4]. Moscow, Sovetskaya entsiklopediya Publ., 1967. 592 p.

4. Averintsev S.S. Khristianstvo [Christianity]. Filosofskaya entsiklopediya. V 5 t. T. 4 [Encyclopedia of Philosophy. In 5 vols. Vol. 4]. Moscow, Sovetskaya entsiklopediya Publ., 1967. 592 p.

5. Athanasius of Alexandria. Tvoreniya. $V 4 t$. T. 1 [The Writings. In 4 vols. Vol. 1]. Moscow, Izd-vo Svyato-Preobrazhenskogo Valaamskogo monastyrya, 1994. $471 \mathrm{p}$.

6. Bulgakov S. Pravoslavie [The Orthodox Church]. Moscow, Terra Publ., 1991. 416 p.

7. Hegel G. Lektsii po istorii filosofii. Soch. T. XI [Lectures on the History of Philosophy. Works. Vol. 11]. Moscow, Sotsekgiz Publ., 1937. 560 p.

8. Gregory of Nazianzus. Tvoreniya. V 2 t. T. 2 [The Writings. In 2 vols. Vol. 2]. Moscow, SvyatoTroitskaya Sergieva Lavra, 1994. 554 p.

9. Gregory of Nyssa. Ob ustroenii cheloveka [On the Making of Man]. Saint Petersburg, Aksioma Publ., 1995. 174 p.

10. John of Damascus. Tochnoe izlozhenie pravoslavnoy very [An Exact Exposition of the Orthodox Faith]. Rostov-on-Don, Bratstvo Svyatogo Aleksiya; Priazovskiy kray Publ., 1992. 446 p.

11. Justin Martyr. Tvoreniya [The Writings]. Moscow, Palomnik Publ.; Blagovest Publ., 1995. 484 p.

12. Losskiy V.N. Ocherk misticheskogo bogosloviya vostochnoy tserkvi. Dogmaticheskoe bogoslovie [The Mystical Theology of the Eastern Church. Dogmatic Theology]. Moscow, SEI Publ., 1991. 288 p.

13. Maksim Ispovednik. Umozritelnye i deyatelnye glavy [Speculative and Actionable Chapters]. Dobrotolyubie. V 12 t. T. 6. [Philokalia. In 12 vols. Vol. 6]. Moscow, Palomnik Publ. 156 p.

\section{Information about the Author}

Olga V. Chistyakova, Doctor of Sciences (Philosophy), Professor of Department of History of Philosophy, Peoples' Friendship University of Russia, Miklukho-Maklaya St., 10/2, 117198 Moscow, Russian Federation, olgachis@yandex.ru.

\section{Информация об авторе}

Ольга Васильевна Чистякова, доктор философских наук, профессор кафедры истории философии, Российский университет дружбы народов, ул. Миклухо-Маклая, 10/2, 117198 г. Москва, Российская Федерация, olgachis@yandex.ru. 